\title{
Plying the Trade Freely: \\ Prostitution and European Union Trade AgreEMENTS IN THE CASE OF ALDONA MALGORZATA JANY AND OTHERS
}

\author{
MIKELA FRENCH*
}

The international debate over sex trafficking has been mired in the debate over prostitution itself. The European Court of Justice's recent Jany decision represents a laissez faire reading of European Union trade agreements. However, by employing a model of Governance Feminism, one may explore the realist consequences of the case for sex workers. Application of the model enables one to examine these shifts in sex workers' bargaining power without deciding whether prostitution is simply work or inherent oppression. The author concludes that such an examination may lead to possibilities for prostitutes to ply both international borders and their trade freely.
Le débat international sur la traite d'esclaves sexuels a été compromis par le débat sur la prostitution elle-même. La récente décision Jany de la Cour européenne de justice représente une lecture de laissez faire des ententes commerciales de l'Union européenne. Cependant, en utilisant un modèle de féminisme de gouvernance, on pourrait explorer les conséquences réalistes de la situation des travailleuses de l'industrie du sexe. L'utilisation du modèle permet d'examiner les changements du pouvoir de négociation de ces travailleuses sans pour autant décider si la prostitution est tout simplement un travail ou de l'oppression inhérente. L'auteur conclut qu'un tel examen peut mener à des possibilités pour les prostitués de manier librement les frontières internationales et leur métier.

\section{TABLE OF CONTENTS}

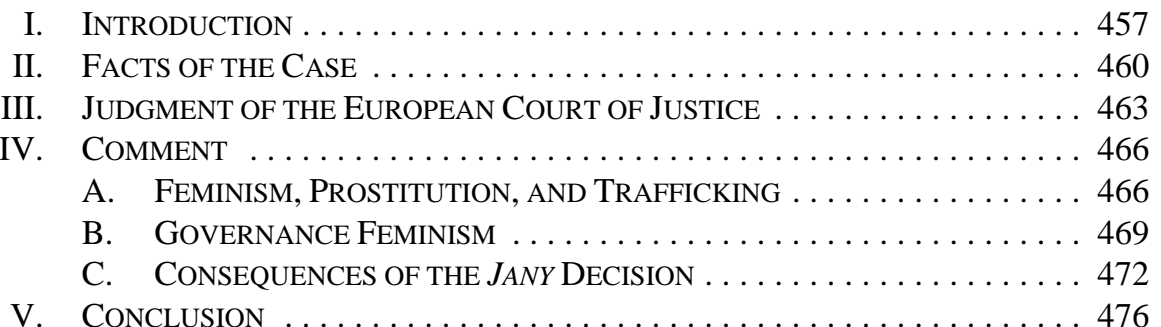

\section{INTRODUCTION}

In international law the term "trafficking" refers to "the illegal and highly profitable practices of recruiting, transporting, or selling human beings into all forms of forced labour or servitude.”1 The U.S. State Department estimates that 800,000 persons are trafficked across borders annually; approximately 80 percent of those trafficked are women, many of whom are forced to work in the sex industry. ${ }^{2}$ Although the State Department's motives for gathering data on trafficking are perhaps skewed by America's interest in citing these

LL.B. Candidate (2008), James E. Rogers Scholar, University of Idaho College of Law.

Nancy Levit \& Robert R.M. Verchick, Feminist Legal Theory: A Primer (New York: New York University Press, 2006) at 221.

2 Ibid. See also Annette Lansink, Committee on Feminism and International Law, International Law Association, Interim Report on Women and Migration (Paper presented to the Berlin Conference 2004), online: International Law Association <http:/www.ila-hq.org/pdf/Feminism\%20\&\%20International\% 20Law/Report\%202004.pdf> at 5; U.S. Department of State, Trafficking in Persons Report 2007, online: U.S. Department of State <http://www.state.gov/g/tip/rls/tiprpt/2007> at 8 . 
statistics in support of sanctions against other nations, even its most conservative estimate of the number of annually trafficked humans is alarming. ${ }^{3}$

Ironically, trafficking is one of the darker consequences of "free trade" as it is currently defined and promoted by Western countries. Due, inter alia, to the historically exploitive devastation of the developing world's economies by wealthier nations, people are being pushed to migration in increasing numbers. ${ }^{4}$ Specifically, declining employment opportunities as well as rising consumer aspirations are factors pushing people to migrate. ${ }^{5}$ People are also being pulled from rural to urban areas, from poor to wealthy nations, by the demands of wealthy nations for low-paid, insecure, seasonal, illegal, and often forced workers. ${ }^{6}$

The push and pull add up to a significant wave of migration. ${ }^{7}$ Yet this wave is dashed against an international regime that is produced by a disciplinary and at times punitive legal order that has been put in place to deal with cross-border movements. ${ }^{8}$ The wreckage of this meeting is where criminal operations scavenge for business opportunities. ${ }^{9}$ Some intermediaries charge huge sums for moving aspiring migrants unlawfully across borders and others use a range of coercive and deceptive practices to extract further profits at the place of destination. ${ }^{10}$ Together they are hugely successful. The total illicit profits produced in one year by trafficked labourers are estimated at US\$32 billion. ${ }^{11}$

Women make up around half of the current wave of migration, ${ }^{12}$ and because of fewer educational and economic opportunities, various customary practices, and representations of women and their roles in societies, women are more vulnerable to trafficking than men. ${ }^{13}$

See 22 U.S.C.A. § 7101; Elise Labott, CNN Washington Bureau, News Release, "U.S. cites 4 Gulf allies in trafficking report” (3 June 2005), online: CNN.com <http://www.cnn.com/2005/US/06/03/ human.traffic/index.html>.

$4 \quad$ See Barbara Stark, "Women and Globalization: The Failure and Postmodern Possibilities of International Law” (2000) 33 Vand. J. Transnat'l L. 503; Kerry Rittich, “Transformed Pursuits: The Quest for Equality in Globalized Markets” (2000) 13 Harv. Hum. Rts. J. 231; Harry Magdoff, "International Economic Distress” (2006) 58 Monthly Review 65 (reprinted from 1982). International Labour Organization (ILO), A global alliance against forced labour: Global Report under the Follow-up to the ILO Declaration on Fundamental Principles and Rights at Work 2005, International Labour Conference, 93rd Sess., Report I (B) (Geneva: International Labour Office, 2005) [ILO Report].

Ibid. at para. 219. Unfortunately, the classification by the ILO of the jobs these workers do as the "3D" jobs - difficult, dirty, and dangerous - creates a euphemism that dilutes the urgency of workers' situations. Also, the ILO unnecessarily assuages the guilt of readers from wealthy nations by describing the jobs further as those that "[n]ationals of the wealthier countries are understandably reluctant to do" (ibid. at para. 219). See also Levit \& Verchick, supra note 1 at 221.

See International Office of Migration, World Migration 2005: Costs and Benefits of International Migration (Switzerland: International Organization for Migration, 2005), online: International Organization for Migration <http://www.iom.int/jahia/Jahia/cache/offonce/pid/1674?entryId=932>. Lansink, supra note 2 at 4. Ibid. See also Curtis J. Milhaupt \& Mark D. West, “The Dark Side of Private Ordering: An Institutional and Empirical Analysis of Organized Crime” (2000) 67 U. Chicago L. Rev. 41; Lansink, ibid.; ILO Report, supra note 5 at 219, 248. ILO Report, ibid. at 219.

See Milhaupt \& West, supra note 9; ILO Report, ibid. at 265.

It is currently estimated 175 million people reside in a country other than the one they were born in, and almost half of those people are women: see Lansink, supra note 2 at 2. 
Women therefore represent half of all economic opportunity for traffickers, and also yield a higher profit margin because they are easier to exploit. Recall that it is estimated that the vast majority of trafficking victims are women, many of whom are in the sex business. ${ }^{14}$ Considered from the perspective of a woman in this position, the term "free trade" sounds terribly absurd.

Dr. Heli Askola notes that this global paradox has played out at the European Union (EU) level as "many EU Member States have followed increasingly convergent paths towards more restrictive policies ... [as part of the] Area of Freedom, Security and Justice" while simultaneously demanding the workforce provided by non-national migrants. ${ }^{15}$ As it has continued to grow, however, the EU has relaxed those policies slightly and entered into association agreements with dozens of countries. ${ }^{16}$ The agreements seek to expand the EU's free trade area, yet stop short of granting full membership rights to association countries. ${ }^{17}$ For example, the agreements grant non-EU nationals from association countries the right to enter and reside in EU countries in order to establish themselves as self-employed persons. ${ }^{18}$ However, simple workers from association countries do not enjoy such free movement into and within the EU. ${ }^{19}$

In 2001, prostitutes from the Czech Republic and Poland, countries with which the EU had association agreements (the countries have since become full members of the EU), ${ }^{20}$ sued the Secretary of State of the Netherlands for the right to enter, reside, and freely establish themselves as self-employed prostitutes. The Netherlands referred the case to the European Court of Justice (ECJ) in Aldona Malgorzata Jany and Others v. Staatssecretaris van Justitie, ${ }^{21}$ and the Court, while recognizing the difficulty of distinguishing between forced and voluntary sex workers, ruled that prostitution is an "economic activity" for purposes of free establishment under the association agreements. ${ }^{22}$ The Court further held that it is the responsibility of the hosting member state to make the determination whether the prostitute is in fact independent and not a trafficking victim. ${ }^{23}$

U.S. Department of State, supra note 2 at 8. Jo Doezema argues that the majority of these women are already employed as prostitutes before they are trafficked: see Jo Doezema, "Forced to Choose: Beyond the Voluntary v. Forced Prostitution Dichotomy” in Kamala Kempadoo \& Jo Doezema, eds., Global Sex Workers: Rights, Resistance, and Redefinition (New York: Routledge, 1998) 34.

Heli Askola, "Globalised Sexual Labour in the EU: Challenging Domestic Debates,” (Paper presented at the 6th Biennial Conference of European Community Studies Association-Canada, 19-20 May 2006), online: European Community Studies Association-Canada <http://www.csac2006.com/pdf/HeliAskola.pdf $>$ at 5.

See online: European Commission <http://ec.europa.eu/comm/external_relations/euromed/free_trade_ area.htm>. Aldona Malgorzata Jany and Others v. Staatssecretaris van Justitie, C-268/99, [2001] E.C.R. I-8615 at I-8618 [Jany].

Ibid. at I-8662, I-8664.

Jany, supra note 17 at I-8664.

EC, Europe Agreement establishing an association between the European Communities and their Member States, of the one part, and the Republic of Poland, of the other part, [1993] O.J. L 348/184 [Association Agreement - Poland]; EC, Europe Agreement establishing an association between the European Communities and their Member States, of the one part, [1994] O.J. L 360/215 [Association Agreement - Czech Republic], collectively referred to as Association Agreements.

$21 \quad$ Supra note 17.

22 Ibid. at I-8689-90.

23 Ibid. at I-8684. 
This decision plays an important part in advancing the fight against trafficking and offers the possibility for some prostitutes to strengthen their bargaining power. Since the 19th century, feminists have been debating whether prostitution can be a valid form of work to which women may consent, or rather if selling sex is always coerced and should therefore be abolished. ${ }^{24}$ Feminists on both sides have attempted to "win" the debate through the crafting of international treaties, but unfortunately, efforts on both sides have failed the large numbers of women trafficked in the sex industry. ${ }^{25}$ In contrast, the Jany decision advances this field because it recognizes the reality that women may occupy a middle ground somewhere between having consented and having been coerced into sex work. Below I argue that the prostitutes who brought the Jany case made a tactical move, by using international trade agreements to force the ECJ to recognize and articulate their relationship to free trade. Further, this approach constitutes an instance of what Janet Halley terms "Governance Feminism," 26 which allows for a discussion of how the decision strengthens women's bargaining power and may help other prostitutes avoid being trafficked in the future.

\section{FACTS OF THE CASE}

Between 1993 and 1996, two Polish nationals and four Czech nationals took up residence in the Netherlands and began working as window prostitutes. ${ }^{27}$ All the women paid rent for places to carry on their business or made substantial income which they recorded with accountants. ${ }^{28}$ Eventually these six applied to the Amsterdam police for permanent residence permits on the basis of the Netherlands' Secretary of State's policy that: “[N]ationals of nonmember countries are entitled to a residence permit only if their presence within national territory is such as to serve an essential national economic interest or if compelling humanitarian reasons or obligations arising under international agreements require that such a permit be granted."29 The women initially argued they should be allowed the permits to work as self-employed prostitutes for "compelling humanitarian reasons."30

Their applications were rejected, and the women lodged objections with the Secretary of State. ${ }^{31}$ Dutch Law states that any foreigner may be refused a residence permit for the Netherlands on grounds of public interest. ${ }^{32}$ Accordingly, the Secretary declared the objections unfounded on the ground "that prostitution is a prohibited activity or at least not a socially acceptable form of work and cannot be regarded as being either a regular job or a profession.”33

See Janet Halley et al., "From the International to the Local in Feminist Legal Responses to Rape, Prostitution/Sex Work, and Sex Trafficking: Four Studies in Contemporary Governance Feminism" (2006) 29 Harv. J.L. \& Gender 335; Berta E. Hernández-Truyol \& Jane E. Larson, "Sexual Labor and Human Rights” (2006) 37 Colum. H.R.L. Rev. 391; Levit \& Verchick, supra note 1; Doezema, supra note 14 .

Ibid.

See Part IV.B, below.

Jany, supra note 17 at I-8666.

Ibid.

Ibid. at I-8664.

Ibid. at I-8667.

Ibid.

Ibid. at I-8664.

Ibid. at I-8667. 
The prostitutes appealed to the District Court, The Hague. The Court set aside the denial of the Secretary of State for "failure to provide reasons," recalling that in 1988, the Secretary of State had granted a residence permit to an Italian prostitute in order to allow her to work and had "thus recognised prostitution as an economic activity." ${ }^{4}$

The District Court next turned its attention to the merits of the prostitutes' claims as they related to the Association Agreement - Poland and the Association Agreement - Czech Republic. $^{35}$ The nearly identical agreements were concluded in order to:

[P]rovide an appropriate framework for political dialogue between the parties ... [and] promote the expansion of trade and harmonious economic relations so as to foster dynamic economic development and prosperity in the [Republic of Poland and the Czech Republic], and to provide an appropriate framework for [those countries'] gradual integration[s] into the Communities. ${ }^{36}$

The Court was concerned in particular with art. 44 of the Polish Agreement (which is similar to art. 45 in the Czech Agreement):

Each member State shall grant, from entry into force of this Agreement, a treatment no less favourable than that accorded to its own companies and nationals for the establishment of Polish companies and nationals.... and shall grant in the operation of Polish companies and nationals established in its territory a treatment no less favourable than that accorded to its own companies and nationals. ${ }^{37}$

The Court speculated that the expression "economic activities as self-employed persons" used in the Association Agreements did not have a meaning different from the expression "activities as self-employed persons" in art. 52 (now, after amendment, art. 43) of the Treaty Establishing the European Community. ${ }^{38}$ The District Court pointed out that "certain forms of prostitution, such as window prostitution and street prostitution, are permitted in the Netherlands and even regulated at communal level by provisions establishing 'soliciting areas." 39 This fact, the District Court concluded, if viewed in light of the freedom of establishment clauses in the EC Treaty and the Association Agreements, might have validated these prostitutes' claims. ${ }^{40}$

More importantly, however, the District Court ruled that the applicants could not invoke the direct effect of the Association Agreements: "It took the view that the replies to the questions raised in that regard by the applicants could not give rise to any reasonable doubt, so that it was not necessary to refer their cases to the [ECJ] for a preliminary ruling." ${ }^{11}$ The

$34 \quad$ Ibid.; supra note 20.

35 Association Agreements, supra note 20.

$36 \quad$ Jany, supra note 17 at I-8660-61.

37 See Consolidated Version of Treaty Establishing the European Community, [2002] O.J. C 325/33, online: EUR-Lex <http://europa.eu.int/eur-lex/lex/en/treaties/dat/12002E/pdf/12002E_EN.pdf> [EC Treaty].

Jany, supra note 17 at I-8667.

Ibid. at I-8668.

Ibid.

Ibid. 
case was therefore sent back to the Secretary of State, who ruled again that all objections to his denials of the permits were unfounded. ${ }^{42}$

The prostitutes lodged an appeal with the District Court seeking annulment of the new decisions by the Secretary of State, and the Court referred the general question whether prostitution is an economic activity for purposes of establishment to the ECJ. ${ }^{43}$

The right of establishment is set out in art. 43 of the EC Treaty. Article 43 states in relevant parts that "restrictions on the freedom of establishment of nationals of a Member State in the territory of another Member State shall be prohibited ...[and] [f]reedom of establishment shall include the right to take up and pursue activities as self-employed persons and to set up and manage undertakings." 44

In articulating its query more specifically the District Court asked five narrow questions:

1. Can Polish and Czech nationals rely directly on the Association Agreements?

2. If the first question is answered in the affirmative, can the Netherlands make the rights of entry and residence subject to monetary requirements?

3. Can prostitution be excluded from the definition of "economic activities" because it is against the morality of the European Union and because such classification would require difficult monitoring of the independence of prostitutes?

4. Can "activities as self-employed persons" in the EC Treaty be distinguished from "economic activities as self-employed persons" in the Association Agreements "so that the activities carried out by a prostitute in a self-employed capacity come within the term used" in the EC Treaty but not the Agreements?

5. If the above distinction is permissible, is it compatible with the Agreements to impose conditions on the self-employed persons, such as skills standards, management requirements, and proof of continuity of business (this last question would be of particular importance to one of the Czech prostitutes because she maintained residence in both the Czech Republic and the Netherlands), in addition to proof of truly independent, non-employee status ${ }^{45}$

Recall that the Netherlands generally reserves the right to refuse residence permits on the basis of public interest and that non-nationals (not covered under association agreements) are only entitled to residency if their presence is essential to an economic interest or presents a compelling humanitarian reason. ${ }^{46}$

Dutch law further seeks to limit the right of free establishment laid down in association agreements by requiring non-nationals to be licensed to practice in their fields (if necessary), to have sufficient financial resources, and to not represent a public danger. ${ }^{47}$ Finally, under

Ibid.

Ibid.

EC Treaty, supra note 37, art. 43. Jany, supra note 17 at I-8669-71.

Ibid. at I-8664.

Ibid. at I-8665. 
the Dutch Circular on Aliens, ${ }^{48}$ application for establishment must be rejected if the activity planned is normally performed in an employed capacity. In order to prove true selfemployment, an applicant may submit documentation from independent persons describing the function the person intends to perform, for example registration with a professional organization, a certificate that Value Added Tax (V.A.T.) tax must be paid, a copy of lease or purchase agreement for professional purposes, or financial accounts. ${ }^{49}$

\section{JUDGMENT OF THE EUROPEAN COURT OF JUSTICE}

Regarding the first issue, and relying on its previous decisions, the ECJ found the Association Agreements establish precise and unconditional principles that may be applied by a national court and are therefore capable of governing the legal position of individuals. ${ }^{50}$ Further, the ECJ recalled its previous rulings that the right of establishment defined by association agreements "means that rights of entry and residence, as corollaries of the right of establishment, are conferred" on non-nationals wishing to pursue industry, commerce, craft or profession. ${ }^{51}$

The ECJ noted, however, that according to the Association Agreements, "those rights of entry and residence are not absolute privileges, inasmuch as their exercise may, in some circumstances, be limited by the rules of the host Member State governing the entry, stay and establishment." 52 This means, the ECJ reasoned, that Polish and Czech nationals "relying on those provisions have the right to invoke them before the courts of the host Member State, notwithstanding the fact that the authorities of that State remain competent to apply to those nationals their own national laws and regulations regarding entry, stay and establishment” in accord with the agreements. ${ }^{53}$

In recognizing the validity of such national laws and regulations, the ECJ answered the second issue referred by the District Court in the affirmative. The ECJ concluded that the Association Agreements do not preclude a system of prior control that makes entry and residence subject to genuine intent to self-employ, sufficient financial resources for carrying out the activity in question as a self-employed person, as well as a reasonable chance of success. ${ }^{54}$

Significantly, the ECJ passed over the third question referred by the District Court and addressed the fourth question out of order: whether the Association Agreements exclude prostitution from the definition of economic activity, even though prostitution has been classified as an economic activity under art. 52 of the EC Treaty. ${ }^{55}$ The ECJ re-examined art. 48 of the EC Treaty as well as settled case law to conclude that providing services for remuneration constitutes economic activity, and such activity must be considered self-

See ibid. at I-8664.

Ibid.

Ibid. at I-8671-72.

Ibid. at I-8673.

Ibid. at I-8672.

Ibid. at I-8671.

Ibid. at I-8674.

Ibid. at I-8675. 
employment if done outside a relationship of subordination. ${ }^{56}$ The ECJ coupled this reading of the EC Treaty with reference to art. 31 of the Vienna Convention on the Law of Treaties, ${ }^{57}$ which says a treaty should be read not only by reference to its terms, but also in light of its object and purpose, ${ }^{58}$ in order to arrive at the following conclusion:

There is nothing in the context or purpose of the Association Agreements between the Communities, on the one hand, and Poland and the Czech Republic, on the other, to suggest that they intended to give the expression ‘economic activities as self-employed persons' any meaning other than its ordinary meaning of economic activities carried on by a person outside any relationship of subordination with regard to the conditions of work or remuneration and under his own personal responsibility. ${ }^{59}$

The ECJ reached this conclusion despite the governments of both the Netherlands and Belgium arguing that prostitution should be excluded from economic activities under the Agreements. $^{60}$

The ECJ elaborated its holding and explained that the principle of non-discrimination in arts. 44 and 45, respectively, of the Association Agreements with Poland and the Czech Republic, covers both the right to take up and pursue economic activities as self-employed persons and the right to set up and manage undertakings. ${ }^{61}$

The ECJ further justified its holding by pointing out that all versions of the Association Agreements, except the Spanish and French agreements, add modifying words which indicate that the rights to establishment set out in those Agreements should not be restricted to industry, commerce, craft, or professions. ${ }^{62}$

Thus, with regards to the fourth issue referred by the District Court, the ECJ concluded that the Association Agreements are not different from the EC Treaty as far as the phrase "economic activities" is concerned and that prostitution "pursued in a self-employed capacity can be regarded as a service provided for remuneration and is therefore covered by both those expressions." 63

Only then did the ECJ turn to the third issue referred by the District Court. Specifically, the District Court asked whether arts. 44 and 45 of the respective Agreements must be construed as meaning that:

[P]rostitution does not come under those provisions on the ground that it cannot be regarded as an economic activity pursued in a self-employed capacity, as defined in those provisions:

-in view of its illegal nature;

-for reasons of public morality;

Ibid.

23 May 1969, 1155 U.N.T.S. 331, 8 I.L.M. 679 (entered into force 27 January 1980).

Ibid., art. 31.

Jany, supra note 17 at I-8676.

Ibid. at I-8678.

Ibid.

Ibid.

Ibid. at I-8679. 
-on the ground that it would be difficult to control whether persons pursuing that activity are able to act freely and are therefore not, in reality, parties to disguised employment relationships. $^{64}$

The first point the ECJ made in addressing the issue is that, according to information from the European Commission, the question is itself "in part based on a false premis[e]." ${ }^{65}$ The ECJ maintained that, contrary to the District Court's implication that most Member States prohibit the activity, ${ }^{66}$ in most Member States prostitution is not prohibited as such; rather, prohibitions, if they do exist, relate to "soliciting, white-slaving, prostitution of minors, procuring and the clandestine residence of workers." 67

Next, the ECJ addressed the District Court's concern about policing the independent status of prostitutes to ensure that, if granted establishment rights, they remain outside of an employment relationship. The ECJ noted that arts. 58 and 59 of the Association Agreements authorize Member States to impose substantive requirements for checks to establish genuine, continuing self-employment. ${ }^{68}$

However, the ECJ recognized the validity of objections made by the Netherlands and Belgium. Those countries argued, in the words of the ECJ, that "prostitution cannot be treated as an activity performed in a self-employed capacity within the meaning of the [Association Agreements] because it is not possible to determine whether a prostitute has voluntarily moved to the host Member State or pursues her activities there freely." 69 The ECJ then continued to characterize prostitution as lending itself to "an 'appearance of independence,' since the criminal prohibition of procuring means that any employment relationships must be organised illegally, [and] prostitutes are normally in a subordinate position in relation to a pimp." ${ }^{70}$ Despite this recognition and elaboration of the difficulty in policing the activity, the ECJ concluded the subject by simply referring to its finding in paragraph 50 of the judgment, that prostitution is economic activity within meaning of the Association Agreements. ${ }^{71}$

With respect to the question as to whether prostitution should not be an economic activity on moral grounds, the ECJ responded that it is not for it to "substitute its own assessment for that of the legislatures of the Member States where an allegedly immoral activity is practised legally."72 It went on to note that while it is true that a host Member State may derogate from the application of the provisions of association agreements on grounds of public policy, doing so presumes a genuine and serious threat affecting fundamental interests of society. ${ }^{73}$

$\begin{array}{ll}64 & \text { Ibid. at I-8580. } \\ 65 & \text { Ibid. } \\ 66 & \text { Ibid. at I-8681. } \\ 67 & \text { Ibid. at I-8680. } \\ 68 & \text { Ibid. at I-8681. } \\ 69 & \text { Ibid. } \\ 70 & \text { Ibid. } \\ 71 & \text { Ibid. } \\ 72 & \text { Ibid. } \\ 73 & \text { Ibid. at I-8682. }\end{array}$


The ECJ observed, however, that prostitution is "tolerated, even regulated, by most [Member] States, notably the Member State concerned in the present case.”74

The ECJ was careful to disclaim that European Community law does not impose a uniform scale of values as regards "conduct which may be considered to be contrary to public policy”; however, a Member State may not justify restrictions on entry and residence if it does not adopt measures to repress its own nationals from engaging in the same conduct. ${ }^{75}$ Derogation, the ECJ explained, is subject to the condition that the host Member State has adopted effective measures to monitor and repress activities of the same kind when pursued by its own nationals. That condition was not met in this case, in particular, the ECJ pointed out, since the Netherlands allows window prostitution and street prostitution, which are regulated at the communal level. ${ }^{76}$

The ECJ finally also acknowledged that part of the District Court's third question involves the concern that Czech and Polish nationals might, under the guise of freely establishing as prostitutes, attempt to gain access to the host labour market. The ECJ dispensed with this concern by pointing out that the Association Agreements do not allow for both selfemployment and employment, in contrast to the EC Treaty. ${ }^{77}$ The ECJ again emphasized that prior control allows for immigration authorities to investigate and verify an applicant's status, and that Dutch law has substantive requirements allowing authorities to ensure selfemployment is intended and obtained. ${ }^{78}$ The ECJ stressed that merely because it is difficult to investigate, Member State authorities cannot "reject an application for establishment solely on the ground that the planned activity is generally exercised in an employed capacity." "The ECJ restated its standard for determining whether a person is self-employed and concluded that national courts should decide if a prostitute is working outside a relationship of subordination, under her own responsibility, and paid directly and in full. If those conditions are met, then the prostitute is engaged in an economic activity as a self-employed person. ${ }^{80}$

The Court did not reach the fifth issue since it made no distinction between prostitution as an economic activity under the Association Agreements and under the EC Treaty. ${ }^{81}$

\title{
IV. COMMENT
}

\section{A. Feminism, Prostitution, ANd Trafficking}

The decision in Jany that prostitution can be considered economic activity under free trade agreements advances feminist advocacy in the area of trafficking because the two favoured feminist, international legal camps working to fight trafficking have reached a stalemate, and Jany offers a way around the impasse. In order to understand the current feminist debate on

\author{
Ibid. \\ Ibid. \\ Ibid. at I-8683. \\ Ibid.; EC Treaty, supra note 37, arts. 48, 52. \\ Jany, ibid. at I-8683-84. \\ Ibid. at I-8684. \\ Ibid. at I-8685-86. \\ Ibid. at I-8686.
}


trafficking, it is necessary to first understand the history of feminist engagement with prostitution. As Janet Halley puts it:

With respect to sex trafficking, the central definitional question is the relationship between prostitution and trafficking, and the relative significance of consent versus coercion in determining a woman's participation in prostitution. Is all prostitution necessarily coercive and a form of trafficking, or is it possible for a woman to meaningfully consent to being a prostitute? ${ }^{82}$

Beginning in the 19th century, feminist activists were concerned with abolishing prostitution on moral grounds. These feminists first condemned regulation of prostitution "as an official licensing of male vice," and later advocated for repressive measures designed to end what they considered a scourge. ${ }^{83}$ Sensationalist media fed the agenda of this social purity movement by decrying the "white slave trade," and telling "titillating tales of deflowered innocence." ${ }^{\prime 4}$ Female prostitutes crossing borders were seen as passive victims, yet "[r]esearch indicates that most of the 'trafficking victims' were actually prostitutes migrating, like thousands of others, in hope of finding a better life." ${ }^{\text {, }}$

The abolitionist push culminated in the 20th century with the League of Nations adopting two conventions concerning the trade in women and children, ${ }^{86}$ and, later, the UN adopting, in 1949, the Convention for the Suppression of the Traffic in Persons and of the Exploitation of the Prostitution of Others ${ }^{87}$ which integrated and superseded the previous agreements. Article 1 of the 1949 Convention requires member states to "punish any person who, to gratify the passions of another: (1) Procures, entices or leads away, for purposes of prostitution, another person, even with the consent of that person, [or] (2) Exploits the prostitution of another person, even with the consent of that person." ${ }^{88}$ These agreements galvanized the view that prostitutes were largely passive victims, and the few women who fell outside that description were seen as morally corrupt anomalies or "fallen women."

This view was not challenged until the adoption of the Convention on the Elimination of All Forms of Discrimination against Women ${ }^{90}$ in 1979 . Although the wording of the treaty regarding trafficking is similar to the above instruments, it can be argued that the abolitionist view lost some ground when Morocco introduced an amendment that would have explicitly called for the suppression of prostitution. The amendment failed, however, because the Netherlands and Italy in particular found suppression of prostitution unacceptable. ${ }^{91}$ What has come to be known as the "individualist" view (because it advocates for taking into

$82 \quad$ Halley et al., supra note 24 at 349.

Doezema, supra note 14 at 35.

Ibid. at 35-36.

Ibid. at 36.

International Convention for the Suppression of the Traffic in Women and Children, 30 September 1921, as am. by the Protocol approved the UN General Assembly on 20 October 1947; International Convention for the Suppression of the Traffic in Women of Full Age, 11 October 1933, 150 U.N.T.S. (entered into force 24 August 1934).

872 December 1949, 96 U.N.T.S. 271 (entered into force 25 July 1951) [1949 Convention].

$88 \quad$ Ibid., art. 1 [emphasis added]; see also Halley et al., supra note 24 at 354.

89 Doezema, supra note 14 at 35-38.

9018 December 1979, 1249 U.N.T.S. 13, 19 I.L.M. 33 (entered into force 3 September 1981) [CEDAW].

$91 \quad$ Doezema, supra note 14 at 39. 
account the view of individual sex workers who choose to prostitute) gained further ground with the General Recommendation 19 of CEDAW in $1992 .^{92}$ The recommendation includes a discussion of poverty and unemployment as factors leading to prostitution and calls for protecting prostitutes from rape and other violence. ${ }^{93}$ Thus the Committee on the Elimination of Discrimination against Women, while not explicitly distinguishing between forced and voluntary prostitution, recognized the prostitute as a subject whose rights could be violated. The individualist approach was finally explicitly articulated in the Declaration on the Elimination of Violence against Women ${ }^{94}$ in 1993 and the draft of the Beijing Declaration and Platform for Action ${ }^{95}$ at the Fourth World Conference on Women in 1995. Both documents recognize the difference between forced prostitution and prostitution. ${ }^{96}$

But while the individualist view has gained ground, it does not predominate. A new school of thought, buttressed by the language of the 1949 Convention, has been gaining prominence. Drawing on radical feminism, the "structuralists," lead by Catharine A. MacKinnon, Andrea Dworkin, and Kathleen Barry, through the NGO Coalition Against Trafficking in Women (CATW), promulgated the idea that prostitution in and of itself is trafficking or slavery:

Women are prostituted precisely in order to be degraded and subjected to cruel and brutal treatment without human limits; it is the opportunity to do this that is exchanged when women are bought and sold for sex.... [L]iberty for men ... includes liberal access to women, including prostituted ones. So while, for men, liberty entails that women be prostituted, for women, prostitution entails loss of all that liberty means. ${ }^{97}$

These radical feminists have achieved recognition and success, most notably at the 1981 Conference in Nice when the UN released a statement that "all prostitution is forced prostitution." 98

Individualists, under the banner of the Global Alliance Against Traffic in Women (GAATW), and structuralists, led by CATW, were both present and clashed during the drafting of the UN 2001 Protocol to Prevent, Suppress and Punish Trafficking in Persons, Especially Women and Children, supplementing the United Nations Convention against Transnational Organized Crime. ${ }^{99}$ The interpretation of this treaty continues to be the main focus in the current trafficking debate. ${ }^{100}$ The 2001 Trafficking Protocol defines trafficking in persons as:

Ibid. at 30; online: UN Division for the Advancement of Women <http://www.un.org/womenwatch/ daw/cedaw/recommendations/recomm.htm\#recom19>.

Doezema, supra note 14 at 40.

GA Res. 48/104, UN GAOR, 1993, Supp. No. 49, UN Doc. A/48/49.

UN Doc. A/CONF.177/20; UN Doc. A/CONF.177/20/Add.1 (1995).

Doezema, supra note 14 at 40.

Halley et al., supra note 24 at 349, quoting Catharine A. MacKinnon, "Prostitution and Civil Rights" (1993) 1 Mich. J Gender \& L. 13 at 13-14.

98

Halley et al., ibid. at 354, referring to the Report of the Special Rapporteur on the Suppression of the Traffic in Persons and the Exploitation of the Prostitution of Others, UN Doc. E/1983/7 and Corr. 1-2 (1983) at 8.

GA Res. 55/5(II), UN GAOR, 55th Sess., Supp. No. 49, UN Doc. A/45/49 (2001) [2001 Trafficking Protocol].

100

See Halley et al., supra note 24 at 358-60; Hernández-Truyol \& Larson, supra note 24 at 399; Lansink, supra note 2 at 10. 
[T]he recruitment, transportation, transfer, harbouring or receipt of persons, by means of threat or use of force or other forms of coercion, of abduction, of fraud, of deception, of the abuse of power or of a position of vulnerability or of the giving or receiving of payments or benefits to achieve the consent of a person having control over another person, for the purpose of exploitation. Exploitation shall include, at a minimum, the exploitation of the prostitution of others or other forms of sexual exploitation, forced labour or services, slavery or practices similar to slavery, servitude or the removal of organs. ${ }^{101}$

Subparagraph (b) states that "consent of a victim of trafficking in persons to the intended exploitation set forth in subparagraph (a) of this article shall be irrelevant."102

During the negotiations, the individualists and some governments wanted to exclude prostitution and sexual exploitation from any mention in the definition of trafficking because they felt conceivable abuses would be covered without it and that the absence of such language would allow for voluntary prostitution. ${ }^{103}$ Abolitionists wanted the 2001 Trafficking Protocol to go as far as the 1949 Convention, which "made prostitution illegal regardless of any showing of consent by the prostituted person." 104 The compromise was that the Protocol would not go as far as the Convention; however, language on prostitution and sexual exploitation was included, and as a result, consent to be trafficked for sex work is now irrelevant if the person consenting is “vulnerable” or under another person's “control." 105 The divergence allows governments to determine their own position on the criminalization of non-coerced adult sex work, ${ }^{106}$ and so the debate continues. ${ }^{107}$

\section{B. GOVERNANCE FEMINISM}

In their 2006 article about feminist legal responses to rape, prostitution/sex work, and sex trafficking, Janet Halley and her colleagues criticize this debate, which they say has led feminists to become entrenched to the detriment of addressing women's real problems. ${ }^{108}$ The debate, they say, either condemns prostitutes and trafficked women as passive victims, ${ }^{109}$ or

Supra note 99, art. 3(a) [emphasis added].

Ibid., art. 3(b). The U.S. Department of State, supra note 2, does not include subparagraph (b) on its website.

Halley et al., supra note 24 at 354 .

Ibid.

Ibid.; Levit \& Verchick, supra note 1 at 222.

Lansink, supra note 2 at 9.

See Halley et al., supra note 24 at 358-60; Hernández-Truyol \& Larson, supra note 24 at 399; Lansink, supra note 2 at 10 . That this debate over consent continues full force is evidenced by the "CATW Statement to the Third Session of the Conference of the Parties to the United Nations Convention against Transnational Organized Crime" (October 2006), online: CATW <http:// action.web.ca/home/catw/readingroom.shtml?x=92306\&AA_EX_Session=3bcfd7ce555c2a39789 fba58cbad7e1d>. In relevant part, CATW complains: "In many UN documents, as well as other instruments, there has been a tendency to not quote the entire definition ... [and] ... omit the phrase, the 'abuse of a situation of vulnerability'” (at 2). The document outlines that the most egregious omission is of art. 3(b) of the 2001 Trafficking Protocol, which refers to the irrelevance of consent. Lansink might counter that this view reinforces patriarchal, cultural norms that view women as vulnerable have served to skew women's reality in terms of migration: "In this scenario men migrate and women are trafficked" (Lansink, supra note 2 at 3).

Halley et al., supra note 24 at 337.

Ibid. at 349. 
idealizes them as actors with unconstrained choices. ${ }^{110}$ What is more, the practice of such feminists, whatever their views on prostitution, has been to advocate for a favorite legal regime internationally, while seeking to apply it to the national level. ${ }^{111}$ The problem, however, is that this approach is based on the erroneous assumption that trafficking will start or stop merely because a law is passed or lifted, rather than recognizing there is always a tolerated residuum of abuse. ${ }^{112}$ Thus, Halley and her colleagues agree, the current paradigm for fighting trafficking is flawed in that it both denies women's realities, and misconceives that the sovereign is the exclusive locus of power. ${ }^{113}$

As an alternate model that overcomes these problems, Halley turns to what she terms "Governance Feminism” (GF), which recognizes the "incremental but by now quite noticeable installation of feminists and feminist ideas in actual legal-institutional power,” but without studying "the resulting feminist reforms as if they will function as sovereign rather than governmental power." ${ }^{114}$ She summarizes the GF project as scrutinizing how feminists come to and do govern, which strands of feminism have worked best to get feminists in positions of power, and the distributive results. ${ }^{115}$ She engages the idea of governance, rather than sovereignty, to "dodge the assumption that all legal power inheres in the state and comes down from a pinnacle of legitimate coercive power." "116 She builds on Michel Foucault's distinction between sovereigntist and governmental or managerial forms of power: "[W]ith government it is a question not of imposing law on men but of disposing things: that is, of employing tactics rather than laws, and even of using laws themselves as tactics - to arrange things in such a way that, through a certain number of means, such-and-such ends may be achieved."

Further, Halley explains, "we assume that the objects of criminal attention, including 'victims' real or putative, are not passive, but engage actively in 'bargaining in the shadow of the law." " 118 GF thus articulates feminist shifts in the rules and the consequent shifts in bargaining power among various stakeholders. ${ }^{119}$

Importantly, this bargaining model advances the fight against trafficking because it bypasses the debate between coercion and consent, and instead allows us to recognize

$110 \quad$ Ibid. at 406

111 Ibid. at 346

112 Ibid. at 342. Indeed, this is the area in which organized crime flourishes: see Doezema, supra note 14; Milhaupt \& West, supra note 9; ILO Report, supra note 5 at 248.

113 Halley et al., ibid. at 339-41.

114 Ibid. at 340, 342 [emphasis in original]. Although Halley et al. are critical of governance feminists precisely because they do not recognize the governmental nature of their own power while simultaneously and somewhat ignorantly advocating for sovereigntist reforms. I use the term GF in a self-aware, rehabilitated sense, to denote a paradigm that incorporates the authors' critique.

$115 \quad$ Ibid. at 337

$116 \quad$ Ibid. at 341

117 Ibid. at 341, quoting Michel Foucault, “Governmentality” in James D. Faubion, ed., Robert Hurley et al., trans., Power: Essential Works of Foucault 1954-1984, vol. 3 (New York: The New Press, 2000) 201 at 211.

$118 \quad$ Halley et al., supra note 24 at 338.

119 Ibid. at 337. This is, of course, not an entirely new concept. Halley herself recognizes this approach as grounded in American legal realism (ibid. at 342). Barbara Stark defines this paradigm as looking at international law as an "international superstore," or tool shed: supra note 4 at 553. 
women as more than passive victims but perhaps something less than freely choosing actors in a world of endless market possibilities. ${ }^{120}$ Annette Lansink, Rapporteur to the International Law Association's Committee on Feminism and International Law, also notes that this view is beginning to take hold: "But a current generation of feminists, motivated by different theoretical positions, and wary of 'grand narratives' of dominance and victimization, have sought to highlight agency and multiplicity of subject positions. The different motives inform the measures that are advocated in the fight against trafficking." ${ }^{21}$ Stark calls this movement a "post-modernism of resistance." 122 It is a recognition of contradiction that feminists can embrace by "abolishing the system while empowering the practice." ${ }^{23}$ In other words, activists may advocate for an end to women's oppression through exploitation of their sex, while also empowering women who do in fact currently perform sex work. Halley’s group terms this a "politics of deferral."124

This bargaining paradigm, which GF defines, is advanced in Jany. Hernández-Truyol and Larson note this in their recent article: "The [ECJ] recently ruled in a case raising the issue of prostitution as work, concluding that sex work is a protected economic activity. However, the Court's ruling shows that it is seeking to reconcile (or perhaps straddle) the work versus servitude debate." 125 The authors point to the tension in the Court's language between the definition of prostitution as economic activity for the purposes of self-establishment, and the requirements that national governments ensure such self-employment is independent, outside of a relationship of subordination, and in return for full remuneration paid directly to the selfemployed person. ${ }^{126}$ Interestingly, this is the extent of these authors' discussion of the case. If one employs the GF model, however, one can examine the distributive consequences of the decision.

It must first be noted, however, that Halley would disagree that a judicial decision can mark an instance of GF:

\begin{abstract}
Although petitions to courts played an important strategy in voicing the feminist perspective, this, I believe, is not a form of GF. While GF is about feminists joining formal political power apparatuses - cooperating with them and operating within them — the courts serve as a venue for those who "lost" the political game or did not have meaningful access to political processes in the first place. Moreover, the adjudication procedure leaves the power in the hands of traditional decision makers — judges — where feminists are relatively passive actors. ${ }^{127}$
\end{abstract}

To apply this opinion to the case at hand, however, would simply revive the consent/coercion dichotomy. To say these prostitutes did not have meaningful access to the political processes

Halley et al., supra note 24 at 407. Hernández-Truyol \& Larson, supra note 24 at 393, come to a similar conclusion with the "crucial insight that sexual labor, like other forms of work, can be exploited." See also Hernández-Truyol \& Larson, supra note 24 at 424-28 for a thorough discussion about deconstructing the consent/coercion debate.

Lansink, supra note 2 at 11.

Stark, supra note 4 at 555.

Halley et al., supra note 24 at 410.

Ibid. at 411.

Hernández-Truyol \& Larson, supra note 24 at 403-404 [emphasis added].

Ibid. at 404.

Halley et al., supra note 24 at 365. 
in the first place assumes that if they had, they either would not be prostituting themselves, or that their prostitution would already be a protected economic activity. Further, it is hard to dismiss the bringing of this case as a "passive" activity. Askola notes that it was the court that was forced into passivity in this case:

Questioning the free will of prostitutes and restricting the growth of sex industries is in obvious tension with the logic of the Internal Market that seeks to facilitate the growth of markets. It is for this reason that the ECJ did not and really could not ask questions about why and how women in prostitution ended up selling sex in the first place, whether enforcing their freedom of movement for prostitution was the appropriate way of improving their situation and what broader consequences that might have for sex industries in the EU. ${ }^{128}$

Whether or not the women who brought this case are feminists employing a particular strand of feminism, they used international/supranational law to create a shift in the rules with distributive consequences that might be said to equate with feminist governance. In particular, they successfully impeded the operation of a national law through employing an international treaty. The resulting freedom from the law is an important form of political power. Karen Engle makes this point in her discussion about how both corporations as well as women often act outside the law: "Recognizing that some actually seek marginality is an important reminder of the difference that power makes, and is an indication that fleeing the margins for the core is not necessarily the best way to attain power." ${ }^{, 29}$ Engle concedes that women have traditionally been losers on the margins, while corporations have had more success there. ${ }^{130}$ But her point, as well as the outcome of this case, reinforces GF's recognition that sovereign law does not hold a monopoly on power. ${ }^{131}$

\section{CONSEQUENCES OF THE JANY DECISION}

On the narrowest reading, Jany can be seen as a clarification of free enterprise, which results in more bargaining power for women who wish to migrate from countries with which the EU has association agreements to EU countries where prostitution is legal. ${ }^{132}$ The number of women seeking to do this may be higher than commonly thought. Doezema argues that "the image of the 'trafficking' victim turns out to be a figment of the neo-Victorian imaginations," and she goes on to cite a 1996 report conducted by GAATW which concludes that "slavery-like conditions in sex work are primarily problems for those already working in the sex trade: thus for prostitutes who migrate." 133 If prostitutes seeking to migrate do indeed make up the largest group of trafficking victims, it is hard not to read Jany as a possibly very useful and important tool. The case may have been overlooked, however, because prostitutes' rights are "unpalatable to the international community: it is one thing to

128 Askola, supra note 15 at 9 [emphasis added].

129 Karen Engle, "Views from the Margins: A Response to David Kennedy” (1994) Utah L. Rev. 105 at 118.

$130 \quad$ Ibid. at 107.

131 But see Stark, supra note 4 at 551: she is wary of metanarratives that simply reinforce women's equality with men. Her point is well taken; if we read Jany within a politics of deferral, we must ask how long before deferral becomes simply neo-liberal complacency.

132 See online: European Commission <http://ec.europa.eu/comm/external_relations/euromed/free_trade_ area.htm>

133 Doezema, supra note 14 at 44. 
save innocent victims of forced prostitution, quite another to argue that prostitutes deserve rights." 134

Thus, it is at the international level that trafficking must be addressed, and this is the level at which Jany operates.

How does the Jany decision accomplish more than a national regime of legalized prostitution can accomplish on its own? Lansink points out that in countries where sex work is criminalized, the "dual illegality of sex work and migration encourages smugglers and traffickers, because the traffickers and pimps threaten trafficked sex workers with deportation if they go to the police.”135 She further outlines that while this situation has led some to call for legalization and regulation so that women can rely on labour law protection, legalization has, in the Netherlands for example, led to brothels simply employing fewer illegal migrants. ${ }^{136}$ She goes on:

Legalising the sex industry, unionism of sex workers to prevent downward pressure on wages by illegal migrants, and EU immigration regulations have contributed to 'keeping the foreigners out' as foreigners would not be able to obtain a work permit to work in licensed brothels. In principle a sex worker without a European Union passport could apply for a permit as self-employed worker if they can prove an economic interest of the state, but this would mostly fail. ${ }^{137}$

In contrast to these restrictions, Jany sets the stage for women to capitalize on the EU's goal of removing barriers to trade in order to freely cross borders across which they might otherwise be trafficked. The result supports the premise that women, at least those from association agreement countries, wishing to work as self-employed prostitutes in countries where nationals work legally as prostitutes, should have both free movement and free sexual enterprise. Again, it is the international shift in bargaining power rather than a sovereign national law that allows women to gain this.

In addition to these immediate effects, however, it can be argued that the case highlights a line of reasoning that can be exploited for further gains by sex workers and trafficking victims. In a case following the Jany decision at the ECJ in 2004, Lili Georgieva Panayotova and Others $v$. Minister voor Vreemdelingenzaken en Integratie, ${ }^{138}$ several prostitutes from association agreement countries were already residing and working in the Netherlands. They applied for permanent residence permits on the basis of self-employment as set out in Jany. The ECJ denied their claims because it found that Dutch immigration authorities did not have the discretion to investigate and grant such requests of a person already residing in the country. ${ }^{139}$ Importantly, however, the Lili decision contrasted the Netherlands immigration

Ibid. at 45.

Lansink, supra note 2 at 12.

Ibid. at 11.

Ibid. at 12. See also Deutscher Handballbund eVv. Marcos Kolpak, C-438/00, [2003] E.C.R. I-4135 at I-4167.

C-327/02, [2004] E.C.R. I-11055 [Lili].

Ibid. at I-8676. The Advocate General's opinion (ibid.) actually found in favour of the prostitutes' claims, on the basis that it is inefficient to make people travel to their home countries uneccessarily. The Court declined to follow this opinion. 
officials with their British counterparts in another ECJ case, Barkoci and Malik. ${ }^{140}$ In that case, the Court found that British officials do have the required discretion to grant residency once an applicant is already in the country, and are therefore obliged to investigate and grant valid requests. The importance of Lili is that women working in the sex industry with illegal status may, in countries where immigration officials have discretion, have their residency legalized, in turn making them less vulnerable to slavery-like exploitation. ${ }^{141}$

Another ECJ case that points to ways in which Jany might be expansively applied is Omega Spielhallen- und Automatenaufstellungs-GmbH v. Oberbürgermeisterin der Bundesstadt Bonn. ${ }^{142}$ In that case, a company wishing to operate a laser-tag facility was stopped by the German government, which claimed such a game, in which players pretend to kill each other, was in contravention of the German Constitution's provision respecting human dignity. The ECJ ultimately agreed that Germany was within its limits to restrict free establishment in this instance. Importantly, the Court noted that there is no EU-wide opinion on the issue of play-killing, but it stated that if there were, "the existence of such general opinion on the need to restrict a fundamental freedom" would be "an indication of its legitimacy." 143 While it is true that in the Jany decision the Court found in favour of the prostitutes on the grounds that the Netherlands may not restrict non-nationals' rights to prostitute because it does not restrict its own nationals' rights to prostitute, the language in Omega suggests the decision might be upheld on the grounds of EU-wide opinion regarding the legitimacy of prostitution. That is to say, since the court in Omega recognized that a restriction on free enterprise might be appropriate on the basis of EU-wide opinion, it might also decide in the future that a restriction on prostitution is not warranted if the wider EU opinion is that prostitution is acceptable. Indeed, it can be argued that such widespread acceptance already exists. As noted above, the Jany Court takes the Netherlands government to task for misrepresenting the acceptability of prostitution throughout the EU, stating that most Member States either tolerate or regulate prostitution. ${ }^{144}$ The possibility that this could be grounds for recognizing prostitutes' right to free establishment under association agreements even in EU countries where prostitution is not tolerated should be explored. ${ }^{145}$

Another possible avenue for prostitutes' EU-wide right to establishment is hinted at in the case of Polok v. Customs and Excuse Commissioners. ${ }^{146}$ In that case, a British court found that V.A.T. must be levied on a brothel, even where the workers had been trafficked, because the trafficking aspect was incidental to the prostitution business, and so not to tax that

The Queen v. Secretary of State for the Home Department, ex parte Julius Barkoci and Marcel Milik, C-257/99, [2001] E.C.R. I-6557.

141 Indeed, my own experience as a volunteer at La Strada, Czech Republic, an NGO advocating for trafficking victims, indicates to me that this would be a huge advantage. Many women coming out of trafficking situations wished, for various reasons, to remain in the Czech Republic and work in the sex industry.

Jany, supra note 17 at I-8684.

Cf. Askola, supra note 15. In commenting on Jany, she agrees with the Netherlands government and states that most EU countries "aim to diminish the scope of the phenomenon, considered unwelcome even in countries where legalization has taken place" (at 9).

146 [2002] EWHC 156; see also Ann Mumford, "V.A.T., Taxation and Prostitution: Feminist Perspectives on Polok” (2005) 13 Feminist Legal Studies 163. 
business would result in unfair competition within the EU. ${ }^{147}$ Perhaps prostitutes wishing to become established in an EU country where prostitution is not legalized could make a claim that prostitutes establishing in other EU countries are benefiting from an unfair advantage.

Further, the Court's ruling in Polok that trafficking is incidental to prostitution could prove useful in a future challenges similar to the prostitutes' challenge in Lili. Women who have been trafficked into an EU country and later wish to become self-employed might be able to make a claim that they should be granted residency without having to return to their home state on the grounds that their original intent was to be self-employed and that the incidence of being trafficked was incidental to that true intent.

Of course, the possibilities presented by Jany are not unproblematic. Askola would disagree that Jany should be embraced and exploited further at all. In her view:

\begin{abstract}
The problem with this laissez faire approach is that while the ECJ was claiming not to take a stand on an issue on which there is little common ground between the Member States, the logic and context of the judgments support the growth [of] prostitution markets, without being able to rebalance the essentially domestic Member State policy concerns about the spread of sex industries and exploitation that they disturb. $^{148}$
\end{abstract}

She further points out that anti-trafficking efforts have been introduced at the EU level "under the Third Pillar, with little attention to how the issue is intertwined with the Community Pillar." ${ }^{149}$ What is interesting about the case, however, is not how it imbalances the pillars, but rather how the Community Pillar becomes the arena in which determination of forced versus voluntary prostitution will be made. As noted above, Hernández-Truyol and Larson recognize that the Court puts the onus of this determination on nations, despite its difficulty. ${ }^{150}$ This means that the regulation of the growth of entry and residence for prostitution will rest largely on the systems of prior control that different nations have in place. As the ECJ stated, it is difficult to determine if prostitutes are truly self-employed; it did reiterate, however, that a nation may make an initial determination whether a would-be prostitute has enough start-up capital to be granted entry and residence. ${ }^{151}$ It logically follows then, that this capital requirement will become the primary locus of regulating self-employed prostitution within the Community Pillar.

Perhaps then the answer for prostitutes will be to turn to expanding micro-credit and banks specifically for sex workers. ${ }^{152}$ Recall that the total illicit profits produced in one year by trafficked forced labourers are estimated to be US\$32 billion. Globally, this represents an average of approximately US\$13,000 per year for each forced labourer, or US\$1,100 per month. ${ }^{153}$ Recall also that profits from trafficking are made both in the transport of women

\footnotetext{
$147 \quad$ Ibid. at 169.

148 Askola, supra note 15 at 9-10.

$149 \quad$ Ibid. at 10.

150 See Hernández-Truyol \& Larson, supra note 24 at 396; Jany, supra note 17 at I-8684-86.

151 Jany, ibid. at I-8671-72, I-8684.

152 “Sex worker bank plans expansion” BBC News (26 October 2006), online: BBC News < http://news.bbc. co.uk/2/hi/south_asia/6064186.stm>. 
and in their continued exploitation. ${ }^{154}$ If women working as self-employed prostitutes could pledge as collateral the promise of the equivalent amount of profit traffickers would otherwise make on their continued servitude, they might quickly meet Member States' standards for start-up capital for free establishment. ${ }^{155}$

Although it is unlikely the ILO had the Jany decision in mind when it did so, it recently recognized the importance of capital to trafficking victims: "While any migration project requires financial and social capital, trafficked victims do not have access to such capital and thus fall prey to criminal groups or individuals that exploit their poverty." 156 If women who would otherwise end up trafficked instead had access to capital (or the recognition of their potential for cash-flow generation), the instances where they might employ a definition of free establishment similar to the one set out in the Jany decision to their advantage could be numerous. For example, the World Trade Organization's 1994 General Agreement on Trade in Services, ${ }^{157}$ stresses that under their "Most-Favoured-Nations Treatment" obligation, WTO Members "shall accord immediately and unconditionally to services and service suppliers of any other Member, treatment no less favourable than that it accords to like services and service providers of any other country." 158 In other words, it might be possible for sex workers to employ the Jany model in other free trade settings.

\section{CONCLUSION}

The international debate over trafficking has been mired too long in the debate over prostitution itself. The ECJ's recent Jany decision represents a laissez faire reading of EU trade agreements; however, by employing Janet Halley's model of Governance Feminism, one may explore the realist consequences of the case for sex workers. What is more, the GF model enables one to examine these shifts in sex workers' bargaining power, without deciding whether prostitution is simply work or inherent oppression. Such an examination may lead to possibilities for prostitutes to ply both international borders and their trade freely.

Ibid. at para. 219.

Cf. EC, Second Council Directive 77/91/EEC of 13 December 1976 on coordination of safeguards which, for the protection of the interests of members and others, are required by Member States of companies within the meaning of the second paragraph of Article 58 of the Treaty, in respect of the formation of public limited liability companies and the maintenance and alteration of their capital, with a view to making such safeguards equivalent, [1977] O.J. L 26/1. ILO Report, supra note 5 at para. 266. 15 April 1994, 1869 U.N.T.S. 183, 33 I.L.M. 1167 (entered into force 1 January 1995). Ibid., art. II(1). 